\title{
列車の主回路電力制御を応用したインテリジェント化 直流鉄道電力システム
}

\author{
正員高木亮（東京大） \\ 正員曽 根悟（東京大） \\ More Intelligent DC Railway Electrical Power Systems \\ with Traction Power Control \\ Ryo Takagi, Member, Satoru Sone, Member (The University of Tokyo)
}

\begin{abstract}
The load of a dc railway has very large peaks, while the average power is low. This makes the capacity of wayside power equipments larger. Recently the ratio of peak power to average power is even higher because of the introduction of a large number of electric multiple units with regenerative brake system. Such introduction has also made the contact system's unreceptiveness of the regenerated energy a significant problem. To solve these problems, researchers are trying to add intelligence to the power system.

In this paper, the authors describe a novel method of intelligently controlling traction power of trains. In this system the trains reduce their accelerating power to cut current peaks in wayside substations. With the proposed method we can reduce load peaks by up to $31 \%$, which means that the characteristics of railway load has been changed drastically. The delays of the trains involved are negligible. Also the unreceptiveness of the regenerated power can be almost eliminated.

In the first part of this paper, we describe the idea of traction power control. Then we describe how the idea is applied to wayside substation load peak suppression or receptiveness improvement, with some simulation results to prove the method. Finally, we discuss the possibility of further improvement of the system by adding communication capability between trains and wayside equipments.
\end{abstract}

キーワード：電気鉄道, き電システム, 主回路電力制御, ピークカット, 回生失効防止制御

\section{1.はじめに}

電気鉄道の負荷電流は, その最大值と平均値の比が 非常に大きい性質をもつ。このため地上に置かれる電 力機器の稼働率は低くならざるを得ない。電力回生ブ レーキをもつ電気車の大量導入は，この傾向に拍車を かけたうえに, 車両のもつ電力回生能力が十分生かさ れない，いわゆる回生失効という問題も浮かび上がら せた。そこで, 電カシステムをインテリジェント化 し,これらの問題を解決することが考えられてい る(1)。例えば，何らかの制御により負荷電流のピーク
を抑制すれば，電力機器の稼働率は上昇する。また， 直流き電システムでは回生失効は回生電力が付近に存 在する別な負荷によって消費されないと起こるので, 回生電力がより遠くの負荷まで届くようにすれば回生 失効は防止できる(2)。

電力システムインテリジェント化に関する従来の研 究では, 地上の電力機器に対して制御をかける方法 （変電所の電圧制御など）がもつばら研究されてき た (2)ー(4)。これに対して, 本論文では列車の主回路電 力を制御する新しい方法を提案する。この方法では, ある変電所の電流が大きい場合に付近を力行中の列車 
が主回路䉓力を狮制することで変電所電流の抑制を図 る。これによれば, 変雨所電流のピークは従来の手法 では考えられないほど(最大䄪 31\%) 激減し，奄鉄負 荷の様相は一変する。また, 主回路電力を制御するこ とにより生じる列車の運行乱れは無視できるほど少な い。また，この手法を応用して回生失効についてもほ ほなくすことが可能である。

本論文では, 列車主回路電力制御の概念を述べる。 次いで、これを応用して変電所電流のピーク抑制およ ひ回生失効防止を行うシステムを列車・地上間通信を 行わずに実現する方法を述べ, 制御の㘯果をシミュレ ーションによって明らかにする。その後, 列車・地上 間通信を行った場合のシステムの改良可能性について も検討する。

なお以下の議論では，列車はすべてインバータ制御 または界磁チョッパを除くチョッパ制御の電気車で, 回生ブレーキをもつものを前提とする。また，駅間で

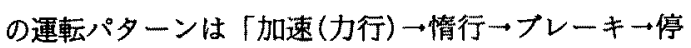
車」という簡単なものを仮定する。

\section{2. 列車主回路電力制御の概念}

$\langle 2 \cdot 1\rangle$ 列車力行電力の制限と列車晴れ(5) 例題 として, 電鉄用変電所の負荷電流のピーク抑制制御に ついて検討しょう。ある変電所の負荷電流のピークを 滅少させるには,

（1）変電所の電圧制御により付近の変電所に救済 させる。

（2）変電所付近の列車の力行電力を減少させる。

（3）変電所付近の列車の運動エネルギーを, 隇速 が必要ない場合であっても回生ブレーキにより き電システムに返させる。

という三つの方法が考えられる。従来の研究ては (1) のみがもっぱら研究されてきたのだが，この方法によ

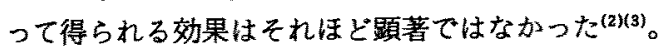

もし，(2)および(3)が使えるならば，ピーク抑制 をより効果的に実現できる。しかし，これを行えば当 然列車は遅れると慗念される。そこで, 列車の力行引 張力を一定時間減少させたときの列車遅れを計算し た。結果を図 1 に示す。加速開始後 15 秒から 25 秒ま での 10 秒間，力行引張力および雨流を最大加速時の 60\%に落としたケースである。絞込み量が大きいにも かかわらず, 遅れは最大 1.3 秒程度と小さく, 通常の 列車運行においては無視できる。

このことから，比較的高速域にある列車ならば，主 回路電力の絞込みによる遅れは通常の列車運行におり る乱れと比べて非常に小さく，効果的かつ大幅なピー

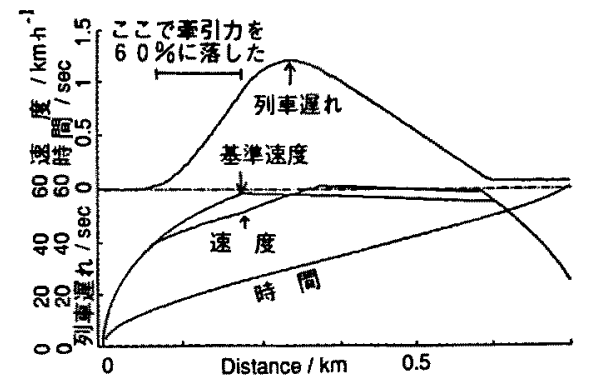

図 1 主回路電力制御と列車遅九

Fig. 1. Calculated delay with main circuit power reduction.

ク抑制を行う可能性があることがわかる。なお,より 低速域での絞込みは大きな道れにつながるおそれがあ るが, 低速では主回路電力も小さく, 主回路電力制御 の効果も小さくなるので, 問題は少ない。

〈2・2〉列車の状態透移による救済 前節の結果 から，低速域以外であれば惰行中の列車が一時的に電 力を回生して減速したり電力を消費して力行すること も同様に可能と考えることができる。これを列車状態 遷移と呼ぶ。この方法を用いることによって, 列車そ れ自体の運動エネルギーを電力の融通に使うことが可 能となる。

これを実現するときには，奻率を不必要に下げない ように列車が，回生のみ」なる状態を新たにもつ必 要がある。通常の「ブレーキ」状態では回生ブレーキ 力が不足すれば, 空気ブレーキによる補足が自動的に 行われる。そこて，「回生のみ」状態では回生ブレー キ力のみでブーキをかけるものとすれば, 空気ブレ 一キによる運動エネルギーのロスを防ぐことができ る。

また，列車状態迷移を回生失効防止制御に応用する こともできる。回生失効が起きそうな場合には情行中 の列車を力行状態に転じさせて負荷を増やせば, 回生 失効を防止できる。

\section{3. 列車・地上間通信を行わない場合の制御法}

〈3・1〉定性的な制御ルールの記述前章で述へ た列車主回路電力制御の考え方を, 変電所ピークカッ 卜制御わよび回生失効防止に応用した場合の制御ルー ルを検討する。

まず,変電所電流のピークを抑制するためには, 列 車は次のようなルールに従って行動すればよい。

(1) 変電所電流が過大ならば, 速度の高い力行列 車は力行電流を絞る。 
（2）変電所電流が過大ならぱ, 速度の高い情行列 車は回生状態に転移する。

また, 回生失効を防止するためには, 列車は次のよ うなルールに従って行動すればよい。

（3）回生車が多ければ，惰行列車は力行状態に転 移する。

なお，このモデルでは列車が力行ないしは情行状態 からブレーキ状態に遷移する条件は「一定減速度で減 速して所定の位置に停止できること」である。従っ て,ブレーキ状態の列車は必ず駅の停止目標を枋ら てブレーキをかけているので, 列車がブレーキ状態に ある間はこのような制御は行わない。

〈3・2〉 フルノッチ比 インバータ制御またはチ ヨッパ制御(界磁チョッパを除く)の電気車であれば, 出しうる最大の牽引力より小さければどんな值でも自 由に好きな率引力を出せる。また，パンタ点からみた 効率が率引力の值によらず一定と仮定する。このと き, 列車速度 $v$ のきに, 列車がその速度における 最大率引力 $T_{\max }(v)$ を発揮している(これを「フル) ッチで加速している」と呼ぶ)ときの電流を $I_{\max }(v)$ とすれば, 牽引力 $T$ を出しているときの電流 $I$ は

$$
I=\left(\frac{T}{T_{\max }}\right) I_{\max }
$$

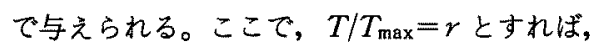

$$
\begin{aligned}
& T=r T_{\max } \\
& I=r I_{\max }
\end{aligned}
$$

と与えられる。、は率引力および電流のフルノッチ時 に対する比率を表すことになるので，これをフルノッ チ比と定義する。なお, フルノッチ比は力行時には $0 \sim 1$, 回生時は $0 \sim-1$ 範囲の值をとるものとする。 従来の走行パターンにおいては, フルノッチ比は力行 時には 1 , 惰行時には 0 , 最大減速度でのブレーキ時 にはー1となる。

以下では,この量を用いて制御アルゴリズムを記述 する。

\section{〈3・3〉 フルノッチ比を用いた制御方針の記述}

まず，列車・地上間通信は行わないから，「変電所電 流が過大」,「回生車が多い」というき電システム側 の状態は, き電線電圧から推定する。列車が知ること ができるき電線電圧はパンタ点のものだけなので, 結 局パンタ点電圧をもとに推定することになる。

変電所電流が大きくなればー般に送出し電圧が下が るので,パンタ点電圧が「低い」ときには変電所電流 が「過大である」と，パンタ点電圧が「低くない」と きには変電所電流は「過大でない」と, それそれ判断 する。また，回生車が多ければき電線電圧が上昇する
ので,パンタ点電圧が「高い」ときには「回生車が多 すぎる」と，パンタ点電圧が「高くない」ときには 「回生車は多すぎない」と，それぞれ判断する。

また，力行電流を絞ることはフルノッチ比を下げる ことである。同様に, 惰行列車が回生状態に転移する のはフルノッチ比を下げることであり, 情行車両が力 行状態に転移するのはフルノッチ比を上げることであ る。

これらから、〈3・1〉節の制御ルールはフルノッチ比 およびパンタ点電圧を用いて次のように晴き換えるこ とができる。

（1）パンタ点電圧が低くなったら, 速度の高い力 行・惰行列車はフルノッチ比を下げる。

（2）パンタ点電圧が高くなったら, 惰行列車は〉 ルノッチ比を上げる。

〈3・4〉 フルノッチ比決定アルゴリスム＼cjkstart前節の 制御ルールに従った制御を実現するためには，力行列 車・惰行列車についてフルノッチ比を従来の走行パ夕 ーンとは違う值にする必要がある。そのためのアルゴ リズムとして，次のようなものを提案する。

(1) 力行列車 力行中の列車は, フルノッチ比 を図 2 もしは (4)式のように, パン夕点電圧によっ て変更する。

$$
r= \begin{cases}r_{\min } & \text { for } V \leq V_{1} \\ r_{\min }+\left(1-r_{\min }\right) \frac{V-V_{1}}{V_{2}-V_{1}} & \text { for } V_{1}<V<V_{2} \\ 1 & \text { for } V \geq V_{2}\end{cases}
$$

ここに, $V:$ パンタ点電圧, $V_{1}, V_{2}:$ 「電圧 が低い」領域の上限を表す電圧定数

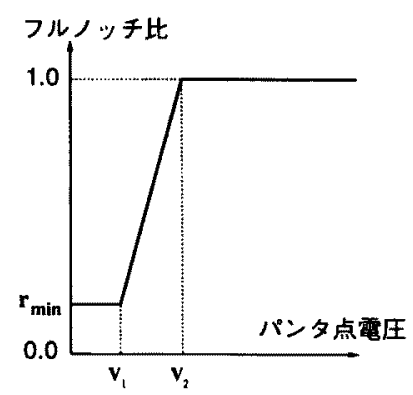

図 2 提案方式における力行車のフルノッチ比パンタ点電圧特性

Fig. 2. Full-notch ratio-pantograph voltage characteristics of accelerating trains. 


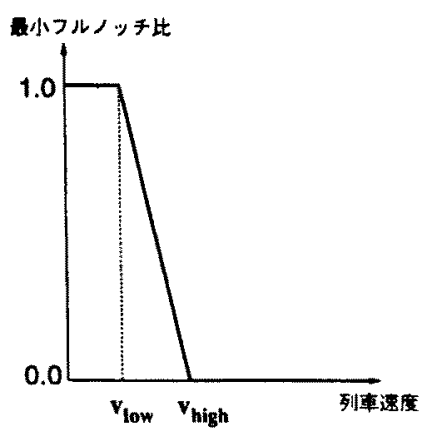

図 3 提案方式における最小フルノッチ比一 速度特性

Fig. 3. Minimum full-notch ratio-velocity characteristics.

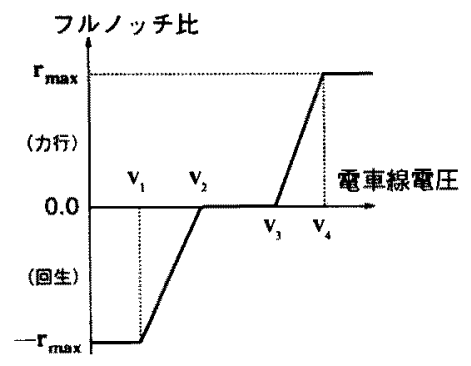

図 4 提案方式における情行車のフルノッチ比一 パンタ点電圧特性

Fig. 4. Full-notch ratio-pantograph voltage characteristics of coasting trains.

(4)式中の変数 $r_{\min }$ は最小フルノッチ比と呼ぶ。 これが 1 であれば「電圧が低い」領域でも力行電力の 絞込みは行われない。また，これが0であれば絞込み がフルに行われる。そこで,この最小フルノッチ比を 速度 $v$ の関数として図 3 もしくは（5)式にて与える ことにより，「速度の高い」列車に対してだけ絞込み を行うようにすることができる。

$$
r_{\min }= \begin{cases}1 & \text { for } v \leq v_{1} \\ 1-\frac{v-v_{1}}{v_{2}-v_{1}} & \text { for } v_{1}<v<v_{2} \\ 0 & \text { for } v \geq v_{2}\end{cases}
$$

ここに, $v_{1}, v_{2}:\lceil$ 速度が低い」領域の上限を

表す速度定数

（2）怌行列車情行中の列車は, フルノッチ比 を図 4 もしくは(6)式のように，パンタ点電压によっ て変更する。「惰行」状態は, 従来全く䋭引力を発揮 しない状態であったが，提案するシステムでは「電圧 が低いと弱い回生ブレーキをかけ、電圧が高いと弱い
力行をし, 電圧が低くも高くもないと何もしない」状 態と再定義光れる。

$$
r= \begin{cases}-r_{\max } & \text { for } V \leq V_{1} \\ -r_{\max }\left(1-\frac{V-V_{1}}{V_{2}-V_{1}}\right) & \text { for } V_{1}<V<V_{2} \\ 0 & \text { for } V_{2} \leq V \leq V_{3} \\ r_{\max } \frac{V-V_{3}}{V_{4}-V_{3}} & \text { for } V_{3}<V<V_{4} \\ r_{\max } & \text { for } V \geq V_{4}\end{cases}
$$

ここに, $V, V_{1}, V_{2}:(4)$ 式に同じ, $V_{3}, V_{4}:$

「電压が高い」領域の下限を表す電圧定数

(6)式における $r_{\max }$ は最大フルノッチ比であり,

(5) 式の $r_{\min }$ を用いて次式のように与えられる。

$$
r_{\max }=1-r_{\min }
$$

4. 列車・地上間通信なしの場合のシミュレー $\forall \nexists ン$

〈3・3〉䬣で述べたように，列車の主回路電力を制御 した場合と，しない場合とについて，シミュレーショ ンを行い結果を比較した ${ }^{(6)}$ 。

〈4*1〉シミュレーション条件 シミュレーショ ンの条件は以下のとおりとした。

(1) 路線：JR山手線

（2）ダイヤ：144 秒周期, 完全に周期的なダイヤ

(3) 車両：小田急 1000 系インバー夕電車 -5 M 5 T 亶加速 最大力行電流 4,400 A - 本数 50 本

（4）変電所：整流器に半導体ダイオードを使用 - 等価内部抵抗 $0.025 \Omega(7,200 \mathrm{~kW}$ 相当)

。無急荷時送出電圧 $1,600 \mathrm{~V}$

（5）き電方式：全線並列き電，変電所母線で上下 線を接続

(6) き電定数: $0.0327 \Omega / \mathrm{km}$

(7) Zの他:

・山手線は独立な系とする。

・列車表定速度は一定とする。ただし，オフブ レーキ運転(駅間走行パターンにおいて惰行が なく「力行ーブレーキ一停車」となる運転パ夕 ーン。このパターンが最短の駅間走行時分を与 える)でも所定の駅間走行時分を下回らない場 合はこの限りでない。

〈4・2〉变電所数通常時 まず, 变電所数が山手 線全線で 11(現状と同じ)の場合について，〈3・4〉節の アルゴリズムに㖞る電圧定数 $V_{1}, V_{2}$ の值を変更し 


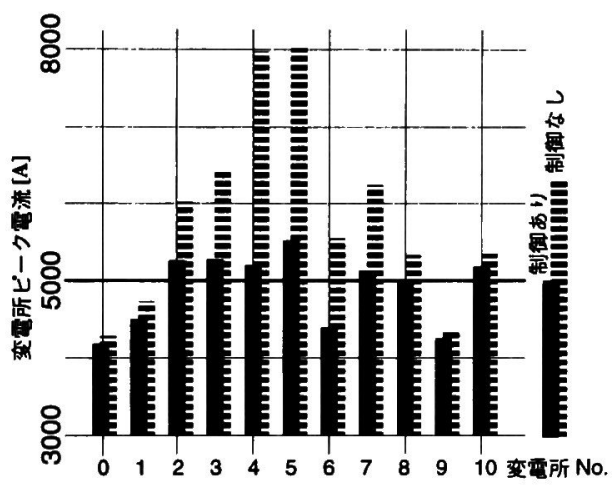

図 5 変電所ピーク電流 (変電所数 11)

Fig. 5. 11 S. S.'s-substation peak current.

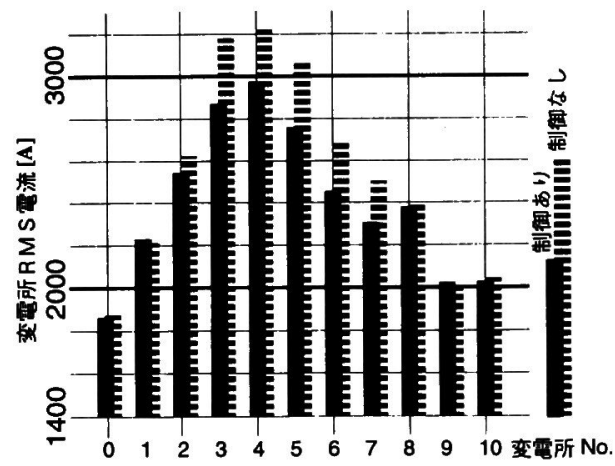

図 6 変電所 RMS 電流 (変電所数 11 )

Fig. 6. 11 S. S.'s-substation RMS current.

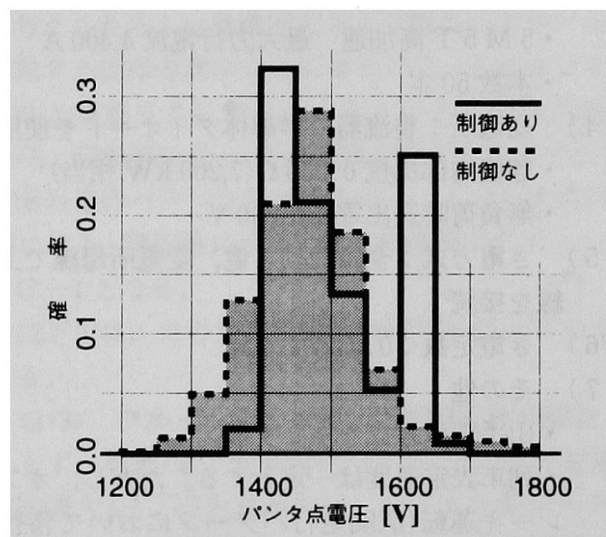

図 7 力行車パンタ点電圧のヒストグラム (変電所数 11)

Fig. 7. 11 S. S.'s - pantograph voltage histogram of accelerating trains.

てシミュレーションを行った。その結果, 変電所電流 の 1 ダイヤ周期(144 秒)あたりの二乗平均平方根(以 下，これを変電所 RMS 電流と呼ぶ)・変電所入力エネ

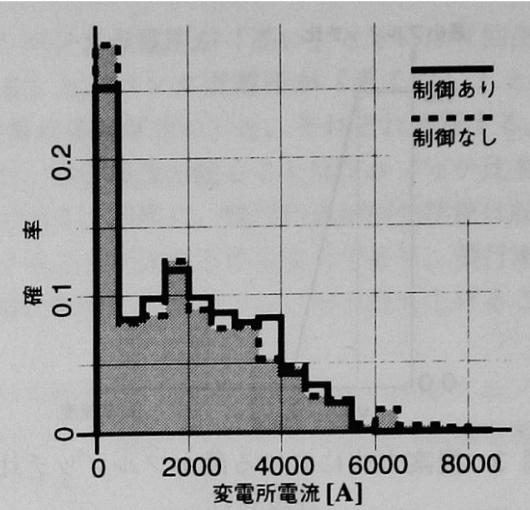

図 8 変電所電流ヒストグラム (変電所数 11 ) Fig. 8. 11 S. S.'s一-substation current histogram.

表 1 その他の評価量 (変電所数11)

Table 1. 11 S. S.'s-other evaluations.

\begin{tabular}{r|l|l}
\hline \multicolumn{1}{c|}{ 項 } & \multicolumn{1}{|l}{ 制御あり } & 制御なし \\
\hline 変電所入カエネルキー $(\mathrm{MW})$ & 31.917 & 31.948 \\
総力行時間 ( $)$ & 4052 & 2793 \\
回生失効率 (\%) & 0.761 & 8.80 \\
回生率 (\%) & 37.6 & 33.4 \\
\hline
\end{tabular}

(i) エネルギーは山手線 1 周分(1時間)の平均とし, 単位 MWで表示した。この値はエネルギーを単位 MWhで表し た場合と数字のうえでは同一になる。

(ii) 総力行時間は内外回り各 2 列車が 1 周したときの力行時間 の合計。

(iii） 力行時間とはフルノッチ比が 0 より大である時間とした。

ルギーの評価量が同時に最小となる值が存在したの で, その点 $\left(V_{1}=1,350 \mathrm{~V}, V_{2}=1,450 \mathrm{~V}\right)$ を最適な点と して, 制御を行わなかった場合と比較した(図 5〜図 8, 表 1)。

ピークカット制御の効果は, ピーク電流值の減少で 最大的 $31 \%$, 非常に顕著である。 RMS 電流につい ても最大約 10\%減少している。このようにピークを 大幅に抑制することができると, 変電所などの機器設 計の考え方が変更でき, 容量低減ないしはコストダウ ンが可能である。また，ピーク率を低く抑制できると 電気鉄道負荷の電力系統からみた性質が従来より良く なるから, 電源が弱い地域での鉄道電化に対する障害 が少なくなる。

また, 従来のピークカット制御では, 救援される変 電所の電圧を周囲より下げるために力行車パンタ点電 圧が低くなる確率が増す。しかし，このシステムでは 惰行車の回生状態への遷移による救援も加わるため に, 電圧がごく低くなる確率はむしろ減少する。一 方, ピークカット制御の結果, 変電所入力エネルギー は上昇するのが普通だが，ここで提案する列車主回路 


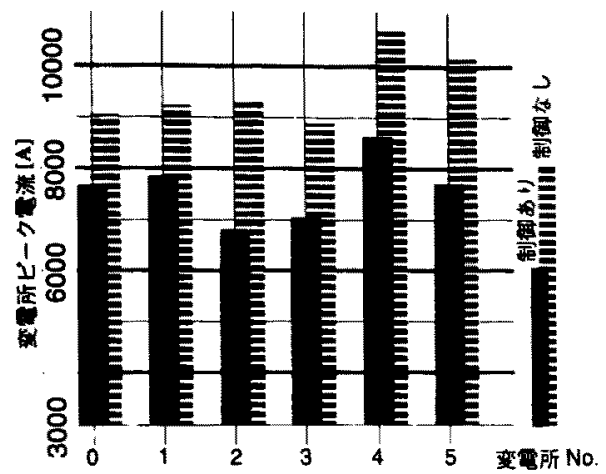

図 9 変電所ピーク電流(変電所数 6)

Fig. 9. 6S.S.'s-substation peak current.

笔力制御によるピークカットでは，後述する回生失効 防止制御の効果もあって変電所入力エネルギーはわず かながら減少している。

総力行時間が非常に大きいのは, 回生失効防止制御 を同時に行ったためである。この回生失効防止制御の 効果で, 回生失効率はほとんど 0 になっている。回生 失效防止のため加速した列車は，走行時分合せのため あとで回生のみ状態に転じるので, 回生失効率低下分 は一部をのぞいて変電所入力エネルギーの低下にも寄 与している。

〈4.3〉 変電所数滅少時 変電所数が 6 と, 通常 より少ない場合についても, 同じ手法でシミュレーシ ヨンを行った。ほほ等間隔に従来と同一容量の変電所 を配置して，〈4・2〉節と同じく $V_{1}, V_{2}$ の最適值を探し た。その最適值 $\left(V_{1}=1,260 \mathrm{~V}, V_{2}=1,360 \mathrm{~V}\right)$ でのシミ ュレーション結果を図 9 , 図 10 に示す。

このケースでも，ピーク電流值の抑制割合は最大約 $28 \%$ と大幅である。RMS 電流值も最大約 $9 \%$ 減少し ているが, 変電所の連続定格以上の電流が流れている 変電所もある。シミュレーション条件は現状のラッシ 二時を想定しているが，1日すべてがこのように重負 荷であるわけではない。変電所の遮断器が過電流を検 知して動作するほどに大きな負荷電流は流れないこと が保証される。そこて，このシミュレーション結果か ら短時間ならばこの方法によって変電所半減でも運転 可能ということができる。

また, 熱時定数が小さい半導体ダイオードなどは, ピーク電流值が大幅に隇少することから実質的に容量 を低隇できる可能性がある。熱時定数が大きい変圧器 などについても，定格を $\mathrm{E}$ 種などのピーク率の高い ものからピーク率の低いものへ変更できることによる コスト低減や，容量低滅の可能性があるといえる。

電学論D, 113 巻 6 号, 平成 5 年

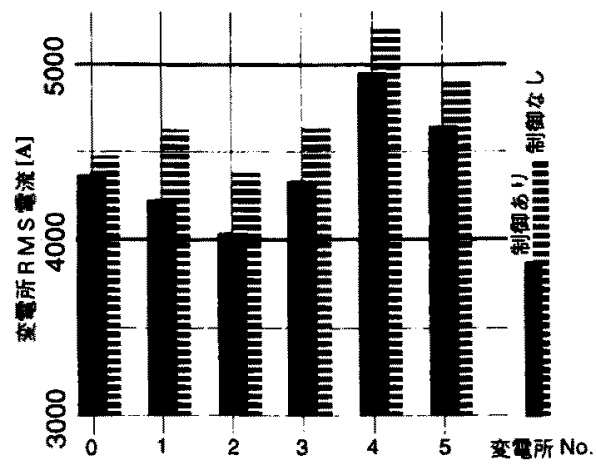

图 10 変電所 RMS 電流(変笔所 6)

Fig. 10. 6 S. S.'s-substation RMS current.

\section{5. 列車・地上間通信による定数 $V_{1}, V_{2}$ の自動 調整}

このシステムに列車・地上間通信を付加することに 上り,システムの更なる改善が期待できる。特に, 列 車群制御システムとのトータル化が実現できれば, 非 常に大きな効果が得られる可能性がある。しかし、こ こではより簡単な改善の可能性として，定数を路線条 件に合わせて自動的に調節することを試みる。

〈3・4〉節に示したアルゴリズムでは，パンタ点電圧 のみを見て制御を行うが，これでは変電所側で絞込み の必要なほど大きな電流が流れていないときに列車が 電流を隇らす行動に出る，またはその逆で絞込みが必 要なときに列車が行動を起こさない，ということがあ り得る。その確率が小さくなるように(4)式および (6) 式の定数 $V_{1}, V_{2}$ を選ぶべきだが, 変電所の配置 は路線の全長にわたって等間隔・等容量とは限らない ことから, 定数値は列車の位置により変えたほうがよ い。また, 地上変電所の容量も常時一定とは限らず, 工事や故障などにより容量が変化するから, 定数もそ れに合わせて変化させる機構があるほうがよい。

一方，エネルギー消費の面からはむだな絞込みは行 わずななるべく変電所電流のピークは高い状態で使う ほうが，エネルギー消費は少なくなる。電流絞込みは 列車の性能を等価的に下げるため，ノッチオフが遅 く，ブレーキ初速が上がるため，エネルギー消費が多 くなる。

そこで, 本章では列車・地上間通信を導入し, 列車 がそれから得られる情報により定数を簡単なアルゴリ スムで自動調整することを考慮し，そのための制御ル 一ルおよび制御の実現手法を検討する。

〈5・1〉通信すべきデータと通信量変電所から 
列車に対して，変電所の全電流を送信すればよい。通 信量は, 山手線のケースについて考えると, 全列車に 対して全 11 変電所の電流值を 0.25 秒に 1 回の割で送 信するとき

$$
4(\text { 回 } / \mathrm{s}) \times 11 \times 16(\mathrm{bit})=704 \mathrm{bit} / \mathrm{s}
$$

となり, 電話線 1 本分の容量とされる $9,600 \mathrm{bit} / \mathrm{s}$ に 遠く及ばないので，特に問題はないと考える。

〈5・2〉制御ルール 定数 $V_{1}, V_{2}$ が過大である と, 変電所の電流が過大でないのに列車が電流を絞込 む確率が多くなる。一方, 定数が過小であると電流が 過大なのに列車が電流を絞込まない確率が多くなる。 また, 省エネルギーの観点からは，絞込みはなるべく 行わないのがよい。

そこで，次のようなルールが考えられる。

（1）列車の周囲の変電所電流が過大でなければ, その列車の定数 $V_{1}, V_{2}$ を下げてフルノッチ比を上げ る。

（2）列車の周囲の変電所電流が過大ならば, その 列車の定数 $V_{1}, V_{2}$ をげてフルノッチ比を下げる。

〈5・3〉 定数調整アルゴリズム＼cjkstart前節で述べた制 御ルールに従った制御を具体化するために，次のよう なアルゴリズムを考えた。時刻 $t$ における変電所電流 を $I_{s p}(t)$, その変電所の許容最大電流を $I_{s m}$, 電流が 過大である領域の下限值を $I_{s c}$, 電流が過大とはなり 得ない領域の上限值を $I_{s l}$ ，と書くことにする。この とき次式が成り立つ。

$$
0<I_{S l}<I_{s c}<I_{S m}
$$

力行車だけが存在するシステムについて考える。あ る時刻 $t$ における列車配置において, 変電所電流が $I_{s p}(t)$ である。列車は電流源に近く, 変電所は電圧源 に近いから, 列車配置が時刻 $t$ と同一で, すべての列 車の電流が $t$ における値の

$$
C_{c}=\frac{I_{s c}}{I_{s p}(t)}
$$

倍である場合を考えると, 変電所電流はおおよそ $I_{s c}$ となろう。同様に

$$
C_{l}=\frac{I_{s l}}{I_{s p}(t)}
$$

倍である場合，変電所電流はおおよそ $I_{S l}$ となろう。

通信は $\Delta t$ 秒ごと(シミュレーションでは 0.25 秒と した)に行うものとする。力行車は，ある時刻 $t$ にお ける $C_{c}, C_{l}$ の值加ら, 次の時刻 $t+\Delta t$ には定数 $V_{\mathbf{l}}$, $V_{2}$ を下のルールに従って変更する。

なお，絞込みが問題になるほど負荷が大きいときに は, 力行車負荷の影響が支配的であろう。また, 定数 の変更アルゴリズムを力行車と惰行車で別にもつこと
も合理的ではない。そこで，惰行車についても，下の 同じルールを適用する。

(i ) $V_{2}-V_{1}=V_{d}$ は一定の値とする。

(ii) $I_{s l}<I_{s p}(t)<I_{s c}$ の場合は定教調整は行わ ない。

(iii） ある列車が仮に力行しているとしたときのフ ルノッチ比 $r_{p}$ を定める。その列車の時刻 $t$ における パンタ点電压を $V_{p}$ とする。また, その列車が時刻 $t$ において保持している電圧定数 $V_{1}, V_{2}$ の值をそれぞ れを $V_{1 p}, V_{2 p}$ とする。 $r_{p}$ は (4)，（5)式より，

$$
r_{p}= \begin{cases}r_{\min } & \text { for } V_{p} \leq V_{1 p} \\ r_{\min }+\left(1-r_{\min }\right) & \frac{V_{p}-V_{1 p}}{V_{2 p}-V_{1 p}} \\ 1 & \text { for } V_{1 p}<V_{p}<V_{2 p} \\ 1 & \text { for } V_{p} \geq V_{2 p}\end{cases}
$$

ただし， $r_{\min }:(5)$ 式で与えられる定数 と与えられる。

(iv) $I_{s p}(t)>I_{s c}$ の場合,フルノッチ比 $r_{p}$ を $C_{c}(<1)$ 倍に減らすことを目標とする。(12)式から, 定数を調節してもフルノッチ比は $r_{\min }$ を下回ること はないことを考慮し，定数調節の目標とするフルノッ チ比 $r_{t}$ を

$$
r_{t}= \begin{cases}C_{c} r_{p} & \text { for } C_{c} r_{p} \geq r_{\min } \\ r_{\min } & \text { for } C_{c} r_{p}<r_{\min }\end{cases}
$$

とする。

(v) $I_{s p}(t)<I_{S l}$ の場合, フルノッチ比 $r_{p}$ を $C_{l}(>1)$ 倍に減らすことを目標とする。(12)式から, 定数を調 節してもフルノッチ比は 1 を上回ることはないことを 考慮し, 定数調節の目標とするフルノッチ比 $r_{t}$ を,

$$
r_{t}= \begin{cases}1 & \text { for } C_{\imath} r_{p}>1 \\ C_{\iota} r_{p} & \text { for } C_{\imath} r_{p} \leq 1\end{cases}
$$

とする。

（vi）列車が時刻 $t$ 現在のその列車の速度およびパ ンタ点電圧のもとで力行していると仮定したとき, フ ルノッチ比が，(13)，(14)式で定めた值になるよう に, 定数 $V_{1 p}, V_{2 p}$ を変化させる。変化後の值 $V_{1 t}$, $V_{2 t}$ は下の式で定められる。この值を, 時刻 $(t+\Delta t)$ におけるその列車の $V_{1}, V_{2}$ として定める。

$$
\begin{aligned}
& V_{1 t}=V_{p}-V_{d}\left(r_{t}-r_{\text {min }}\right) \\
& V_{2 t}=V_{1 t}+V_{d}
\end{aligned}
$$

〈5・4〉 シミュレーション結果シミュレーショ ンは,〈4・1〉節にて示した条件で, 変電所数 11 の場合 


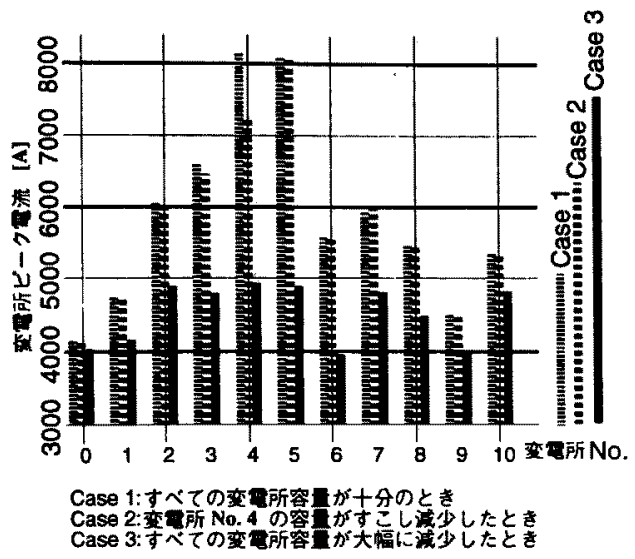

図 11 電圧定数の調整と変電所ピーク電流 Fig. 11. Voltage constant abjustment and substation peak currents.

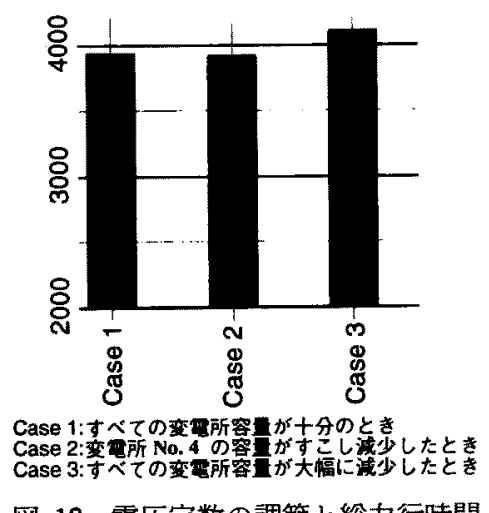

図 12 電圧定数の調節と総力行時間

Fig. 12. Voltage constant abjustment and total accelerating time.

について行った。結果を図 11 , 図 12 に示す。

ケース 1 は $I_{s l}=9,600 \mathrm{~A}, I_{s c}=12,000 \mathrm{~A}$ の場合で, 容量が十分のためほとんど絞込みが行われていない。

ケース 2 は変電所 No. 4 のみ $I_{s t}=4,800 \mathrm{~A}, I_{s c}=$ $7,200 \mathrm{~A}$ とした場合で, この変電所だけ電流ピークが 抑えられており，他の変電所が影響を受けてピーク電 流值が大きくなるような現象も現れていない。このよ うに, 変電所の特性のある程度の変化に対しても, 列 車・地上間通信を付加すれば簡単なアルコリズムで柔 軟に対処が可能であることがわかる。

ケース 3 は全変電所について $I_{s l}=3,600 \mathrm{~A}, I_{s c}=$ $4,800 \mathrm{~A}$ とした場合で, この場合でもピーク電流は抑 制されている。しかし, 列車の総力行時間が増大し, 列車は遲れ，エネルギー消費が増加している。このよ うに，大幅に変電所の容量が減少した場合には，この

電学論D, 113 巻 6 号, 平成 5 年
制御ルールでは変電所ピーク電流の抑制については有 効であるが，それ以外の評価量を最適化することがで きないことがわかる。

列車・地上間通信の存在を前提とした列車群制御シ ステムと電力システムの協調により，より大幅な改善 の可能性が開けてくる。ケース 3 のよう場合にも対 応してエネルギ一消費などの異常な増加を防ぐには， 余裕時分の再配分や適切な遅れ指示など, 列車群制御 システムとの連係がどうしても必要である。一方, 列 車群制御を適切に行えば, 列車の性能が等価的に上が ったような効果が得られ，生み出された余裕を電力シ ステム最適化のためにまわすことも可能になる。

\section{6. まとめ}

本論文では,

（1）列車主回路電力制御による鉄道電力システム のインテリジェント化の可能性を示した。次いで, 変 電所電流ピーク抑制および回生失効防止制御にこれを 応用したシステムを提案し，このシステム導入による 効果は非常に大きいことを示した。また，副作用とし ての列車の運行乱れが無視できるほど小さいことを同 時に明らかにした。

（2）このシステムに列車・地上間通信を組み合わ せ, 列車がもつ制御用のパラメータを自動調整するア ルゴリズムを提案し, 変電所容量が変化した場合で も，このアルゴリズムによればピーク電流を確実に抑 制することが可能であることを示した。しかし，列車 群制御システムとの協調がないと，ピーク電流を抑制 すること以外のパラメータを最適にすることは難しい ことも述べた。

本論文の成果は,インバータ制御またはチョッパ制 御(界磁チョッパを除く)の電気車が走るほとんどの直 流電気鉄道に応用可能であり，その効果も大きい。変 電所容量が不足して鉄道の輸送力増強を阻んでいるケ 一スは多く,それらへの適用により輪送力不足を 1 日 も早く解消することが期待される。

(平成 4 年 6 月 22 日受付, 同 4 年 12 月 8 日再受付)

$$
\text { 文献 }
$$

（1）「電気鉄道のインテリジェント化」，電気学会技報(II 部)， No. 341 (平 2)

（2）松富・曾根：「回生車能力の有効利用について1、第 4 回日本 シミュレーション学会研究発表会 (昭 58)

（3）松富：「回生車を含をき電システムの最適化」, 東大工学部 電子工学科修士論文 (昭 59)

（4）「回生車を含むき電システムの現状とあり方」，電気学会技 報 (II部)，No. 296 (平元)

（5）高木・曾根：「インテリシェンスの拿入による電鉄負荷のピ 一クカットj, 电気学会交通・惺無鉄道/道路交通合同研資， 
TER-91-1; RTA-91-1 (平 3)

（6）高木・曾根：「鉄道電カシステムのインテリジェント化(その 2)」, 電気学会交通・電気鉄道研资, TER-91-36 (平 3)

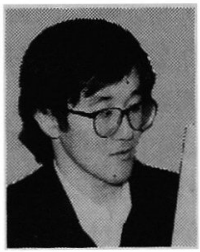

高木亮 (正員)

昭和 42 年 6 月 14 日生。平成 4 年 3 月 東京大学大学院工学系研究科電気工学専 攻修士課程修了。同年 4 月同専攻博士課 程に進学, 現在に至る。鉄道電カシステ ムおよび鉄道のインテリジェント化に関する研究に従事。 IEEE Student member。

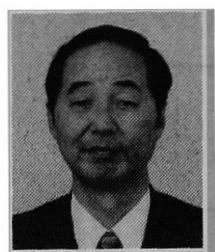

曾 根悟 (正員)

昭和 14 年 4 月 23 日生。 42 年東京大 学大学院博士課程修了。59 年東京大学 電気工学科教授, 現在に至る。工学博 士。パワーエレクトロニクスと交通シス テム工学の研究に従事。電気学会論文賞, JREA 賞, 市村 賞, 交通図書賞受賞。電子情報通信学会会員。

\& \& \& 